\title{
Does Foreign Ownership Influence Firm Profitability? Evidence from the Tunisian Context
}

\author{
Dabboussi Moez $^{1,2}$, Kouki Marouan ${ }^{1} \&$ Rajhi Mohamed Tahar ${ }^{1,2}$ \\ ${ }^{1}$ Faculty of Economics and Management of Tunis,Tunisia \\ ${ }^{2}$ Researchers and members of scientific and academic council of IAE, Tunis, Tunisia \\ Correspondence: Kouki Marouan, Faculty of Economics and Management of Tunis, Tunis, Tunisia. E-mail: \\ koukimarouan@yahoo.fr
}

Received: May 3, 2015

Accepted: May 27, 2015

Online Published: July 25, 2015

doi:10.5539/ijef.v7n8p159

URL: http://dx.doi.org/10.5539/ijef.v7n8p159

\begin{abstract}
The aim of this paper is to examine the impact of foreign ownership on the profitability of Tunisian financial institutions. Empirical evidence shows (i) that the foreign ownership has a positive and significant effect on firm profitability as measured by return on assets and return on equity. (ii) The presence of foreign directors in the board causes also an increase in return on assets. (iii) However, contrary to previous studies, state-owned firms seem to perform better than fully privatized companies.
\end{abstract}

Keywords: foreign ownership, profitability, private property, privatization, financial institutions

\section{Introduction}

One of the most striking facts about twentieth century's economic history was the predominance of the state over the entire economic activity, which explains the recorded strong economic increase. At that time, state intervention played a central protective role against market failures and ensured a rational economic development. However, this progressive intrusion in the economy had negatively affected the national economies of developed and developing countries. As a result, recent years were characterized by a slowdown in economic increase, rising inflation and rising unemployment. This situation encouraged world economies to follow a universal orientation to redefine the place and role of the state in the economy. Therefore, it was necessary for states to disengage their economies by attracting maximum foreign capital and allowing them to participate in public firms.

Previous literature on this field extensively studied foreign ownership in order to explain the importance of the presence of foreign investors as a key of economic performance (Megginson, 2005). The vast literature offers several explanations for these patterns and yet the issue remains totally unresolved. Gupta N. $(2001,2005)$ and Lars and Trond (2003) found that firms partially privatized seem to be more successful than fully privatized firms. Like most developing countries, Tunisia's economy has been going through a reform process after decades of state control. This transformation aims at promoting foreign investment, restructuring of public enterprises and encouraging a commitment to a crucial program which develops partnership with foreign financial institutions. In other words, the successful Opening to foreign capital experience of financial institutions in transition countries such as Hungary, Argentina and Mexico should be recommended for an emerging country like Tunisia.

Our study focuses on the effects of foreign ownership on firm profitability. In particular we focus on Tunisian listed financial institutions. We consider banks and insurances companies for two main reasons. On one hand; the Tunisian banking system has experienced in the last decade several reforms encouraging franchise to foreign competition and the achievement of partnership operations with foreign financial institutions. On the other hand, the insurance sector is one of the cornerstones of modern financial services that play an important role in covering economic and financial risks. To this end, this paper will be organized as follows: the second section will present a review of the literature. The third section present our sample and model specification. The interpretation of the results will be subject of the fourth section. Finally, the fifth section concludes the paper. 


\section{The Literature Review}

Foreign investments are the center of economic development. They occupy a special place in most countries seeking to draw more capital through financial liberalization, privatization and IPO. First, financial liberalization (Note 1) is an opportunity for foreign investors to acquire large stakes in domestic companies. According to recent trends of economic liberalization, foreign investors can improve benefits of diversification, driving up local equity price, purchasing more stocks and bonds which make the economy more liberal and more consistent with the liberal doctrine where the state should not intervene.

Similarly, studies of emerging countries show that more open economies perform better than those restricted. Then, the presence of these investors depends on how privatization is developed in the economy. For example, the method of the direct sale of a business is always favored and attracts the attention of foreign investors. Similarly, the method of public offering, which is usually preceded by direct sales, is a sign of a healthy company and a growth potential. Moreover, it is important to note that privatization objectives cannot be achieved only if privatization promotes foreign portfolio investments. This type of intervention is a real participation in the privatization process. Roosenbooma et al. (2003) reported that IPO reduces information between issuers and investors since companies constrained by asymmetric information are encouraged to publish their financial statements on a daily basis which is a good sign for investors on the quality and intrinsic performance of the firm. Moreover, IPO facilitates the adoption of privatization mechanisms (total or partial) because of the existence of indicators published on daily activities such as earnings and dividends. These indicators are then used and targeted by investors, who are interested in productive investment, will carefully monitor the evolution of this information before taking the decision to actively invest on a foreign stock exchange.

\subsection{The Benefits of Foreign Investment}

Economic analysis showed many reasons and possible explanations for foreign investment. In the same line of thinking, sustainability of firms with foreign participation depends on the competitive advantages they can develop in a deregulated sector, which are difficult to reproduce by competing firms. Among the advantages of partnering with foreign firms we mentioned, first of all, the research for greater efficiency. Indeed, most research focuses on the impact of privatization (partial or total) on the efficiency of firms inspired by earlier work on agency theory that focus on the efficiency through maximizing shareholder wealth. These latter are considered as the only owners while managers act as agents (Alexandre \& Charreaux, 2004). Similarly Maw (2002) confirmed that the most important objective of a restructuring program is carried out by the state is efficiency and the transfer of property rights to the most productive entrepreneurs to ensure proper management options. At the national level, several authors studied the effects of financial liberalization on the efficiency of the Tunisian banking system. They found that foreign partners provide domestic banks a higher exposure to the practical world, as well as preferential access to training, technology and human capital. Therefore, these banks benefit from improved efficiency. In this context Mamoghli and Dhouibi (2009) studied the impact of public ownership on the profitability of Tunisian banks and they found that state ownership negatively affects efficiency.

La Porta et al. (2002) showed that in all countries, mainly in developing countries, the public ownership in commercial banks is a source of their lack of efficiency. Then, partial privatization is an effective source of funding and wealth creation. Indeed, reducing the budget deficit and public debt is among the objectives of the most exhibited by partnership programs across developed economies and developing economies. Reducing this constraint has often been recommended as a structural adjustment and stabilization policy. Then foreign investment may be beneficial for the banking system in transition (La porta et al., 1999). Indeed, Dinger (2009) showed that public private banks as a multinational firm act as a stabilizer of the banking system of these countries. This role could be promoted through access to diversified sources of international liquidity. Similarly, Oxelheim, and Randoy (2003) found that the presence of foreign directors is perceived by investors as a signal of transparency and willingness to improve governance in the public firm. In another context, Gupta (2005) argues that financial markets can mitigate agency problems through the separation of ownership and control. Amess and Girma (2009) conducted a systematic analysis of causal effects in varying degrees of privatization, they found that full privatization is the main factor that contributes the improvement of labor productivity. However, it also creates job losses. The results of partial privatization are particularly striking and they can be summarized in a significant improvement in labor productivity, job creation and wage growth which constitute a "win-win" strategy between the public sector and the private sector.

\subsection{The Limits of Foreign Investment}

The main shortcomings of foreign investment are generally related to public ownership. Indeed, such an 
operation combines the gaps in private firms and public firms. In fact, it is very well known that investment requires an entry new management practices. The compliance with the contractual terms of these practices is difficult for countries in transition because of the weakness of their institutions in legal term. Therefore, a moral hazard is observed since cash flows from this investment are shared between the government and the new owners. The latter will have little incentive to invest therefore the net present value of income is reduced. Similarly, administrative feasibility can also be a constraint for the public sector.

The presence of foreign investors as strategic partners who must satisfy the public interests by generating benefits for all partners is not always obvious. Indeed, their presence can yield unexpected results, such as poor service or high cost of use. This moral hazard can be mitigated by two concepts: trust and control (Leroux \& Sauvee, 2004). According to Lensink and Naaborg (2007), the lower performance of foreign banks might be the existence of information asymmetry between the owner in the home country (the principal) and the managers of the foreign subsidiary in the host country (the agent). This information asymmetry might, for example, induce the foreign parent to approve only low risk credit proposals submitted by the foreign subsidiary. Moreover, Demirguc-kunt and Detragiache (1998) show that there is a positive relationship between financial liberalization, deregulation and banking crises. This result confirms that internationalization of the financial system without preparing national institutions can lead to a systematic increase in banking crisis risks. This problem becomes even more important when companies are larger and the gap between cultures is wider Haspeslagh and Jemison (1991). Furthermore, Berger et al. (2004) concluded that it is difficult for financial institutions to operate in a foreign country because of differences in language, laws and regulations.

\subsection{The Relationship between Foreign Ownership and Profitability}

Most theoretical and empirical studies in this area support the point of view of the positive effect of privatization on firm performance (Megginson, 2005; Megginson \& Netter, 2001). Gupta (2005) found, with a sample of 40 Indian public firms, a significant improvement in profitability growth rate, labor productivity and expenses. Levine (2004) confirms the importance of foreign ownership on the performance of domestic banks by showing that barriers to entry of foreign banks have a positive impact on net bank interest margins. Similarly, Ben Naceur.et al (2007) found that changes in profitability of privatized firms negatively correlate with state control and positively correlate with foreign ownership, which shows the importance of foreign participation. Lin and Zhang (2009) found that banks partly acquired by foreign companies are more successful than those which kept their ownership structures. Wu and Strange (2000) found that foreign insurers have an important role in maximizing revenues by promoting investment and improving profitability when they have easy access to capital markets. However, other researchers concluded that entry of foreign capital negatively affects profitability. Indeed, the results of Claessens et al. (2001), based on a sample of 80 developing countries, indicate that foreign entry improves the implementation of national banking markets. However, easing restrictions on entry may reduce domestic banking profits (Boubakri et al., 2005). According to Lensink and Naaborg (2007), banks with a low degree of foreign ownership are more profitable and able to raise more net interest revenues than banks with a high degree of foreign ownership.

\section{Data and Methodology}

\subsection{The Sample}

Our sample consists of 13 financial institutions (Note 2) listed on the stock exchange of Tunis (TSE). These financial institutions have more than $49 \%$ of market capitalization. For each of these companies, observations are made over a period of 11 years, ranging from 2000 to 2011. The data are collected from the stock exchange of Tunis (TSE), the Tunisian Federation of Insurance Companies (FTUSA) and the Professional Association of Banks and Financial Institutions (APBT). The choice of variables in our database is made in accordance with recent studies on banks profitability.

\subsection{Choice of Variables and Hypotheses to Be Tested}

\subsubsection{The Dependent Variables}

We measure profitability by three proxy variables: (i) The first dependent variable is returns on assets (ROA) and defined by the ratio of the company's earnings before tax in a given period to the total value of its assets. This ratio, referred to as "return on investment", gives information on the capital intensity of the firm and shows also the return generated for each unit of invested assets. This ratio has an average of 0.01 and a low variability (0.017). (ii) The second dependent variable is returns on equity (ROE) defined as net income to total equity. This ratio measures the return rate on the common stock owners used to measure a firm's efficiency for each unit of invested equity. This endogenous variable has a mean of 0.052 and a variability of 0.26 . (iii) Finally, the rate of 
return (RB) over the period t-1 to $t$ is the percentage change in stock price (Note 3) (Pt-Pt-1)/Pt-1 during closing $31 / 12 / \mathrm{N}$. It has a mean of 0.1107 and a variability of 0.457 .

\subsubsection{The Explanatory Variables}

We distinguish two categories of variables: Variables related directly to the proposed theory (considered as main variables) and control variables. Consistent with previous empirical works, we use in our research the following variables:

Variables representing ownership structure: Several studies have shown that ownership structures (public, private, foreign) are important in explaining profitability of a financial institution. However, these studies reached contradictory and inconsistent results.

-The variable foreign ownership (Foreign) is measured by the percentage of shares held by the citizens or foreign institutions (all nationalities). Then we suppose a positive and significant relationship between foreign ownership and the profitability of financial institutions (H1).

-Similarly, Public ownership (Public) is measured by the percentage of shares owned by the state. Then we expect a negative and a significant relationship between Public ownership and profitability (H2).

-Private Property (Private) is measured by the percentage of shares held by companies or private individuals. This variable reflects the proportion of shares held by institutional investors. Then we suppose a positive and $a$ significant relationship between profitability and financial institutions ownership (H3).

-Foreign board member (FBoard) is a dummy variable that takes the value 1 for the financial institutions that have foreign investors as their board members and 0 otherwise. Then we expect a significant positive effect of Foreign board member on profitability (H4).

-Finally, domestic blockholders (Bloc) is determined by the percentage of shares held by the three major domestic shareholders who combine the functions of management and their influence on the decisions taken by the Board of Directors. we suppose a positive and and significant relationship between domestic blockholders and profitability (H5).

-Control variables: We introduce the most two control variables used by the literature: (i) The first variable is measured by the number of branches (Branch) for the financial institution in a year. It reflects the ability to access the services of the financial institutions since an extended service branches could meet the demand of customers and thus contributes to an improvement in profitability. (ii) The second control variable is the Annual growth rate $(\boldsymbol{T C C A})$ measured by the increase in sales $(\mathrm{CA})$ over a specific period of time: $\mathrm{TCCA}=100 *(\mathrm{CAt}-$ CA t-1) / CAt-1.

\subsection{Model Specification and Estimation Methodology}

The econometric formulation proposed in this study examines the effect of foreign partner ownership on firm profitability. According to Lars and Trond (2003), the empirical model to be tested is presented in the following form:

$$
\operatorname{Pr} f_{i t}=\beta_{0}+\beta_{1} \text { Foreign }_{i t}+\beta_{2} \text { Public }_{i t}+\beta_{3} \text { Private }_{i t}+\beta_{4} \text { FBoard }_{i t}+\beta_{5} \text { Bloc }_{i t}+\beta_{6} \text { Branch }_{i t}+\beta_{7} T C A A_{i t}+\varepsilon_{i t}
$$

Where Prof $f_{\text {it }}$ is Profitability as measured by return on assets (ROA), Return on Equity (ROE) and stock return (RB) for ten firms $(i=1, \ldots ., 10)$ and over the period 200- 2011. the model will be analyzed by using the panel method. Our estimation is conducted in three regressions where the difference lies only in the measurement of the dependent variable ROE, ROA and RB respectively. The estimation of the three models will be processed by "STATA" software. To do this, we test homogeneity (note 4) of our sample, i.e. to check for specific individual effects.

\subsection{Test of Homogeneity}

By using panel data, homogeneity analysis (Table 1) allows us to know the adequate specification which should be tested. This test is done in two steps: the first one is to test individual effects (choice between individual and common effects) and the second is the hausman test (choice between fixed and random effects). For the dependent variable return on assets, performing the homogeneity test (as shown in the table) allows us to conclude about the presence of a heterogeneity problem.

Therefore, the method of Ordinary Least Square (OLS) will be biased. Then, we estimate model 1 with specific fixed and random effects. Then we choose the model to be used (fixed or random). The Hausman test which aims at choosing the model to be used has allowed us to choose the random effects model as $\mathrm{P}(\chi 2)=0.1459>0.05$. 
For Model 2, we retain the random effects model (as $P(\chi 2)=0.1254>0.05$ ). Similarly, for Model 3., we retain the fixed effect model $\left(\right.$ as $\left.\mathrm{P}\left(\chi^{2}\right)=0.0113<0.05\right)$.

Table 1. Hausman test

\begin{tabular}{cccc}
\hline Regression & model 1 & model 2 & model 3 \\
\hline$X^{2}$ posted & 10,43 & 10,70 & 15,50 \\
Probability & 0,1459 & 0,1254 & 0,0113 \\
Fixed or random effect & Random effect & Random effect & Fixed effect \\
\hline
\end{tabular}

\section{Results Estimations and Discussions}

\subsection{Descriptive Statistics of All Variables}

We started with a descriptive analysis (Table 2) for each variable for all financial institutions in our sample shows:

- Profitability variables: Return on assets (ROA) has a mean of $1.05 \%$ with a maximum value of $7.35 \%$. Similarly, we found that return on equity (ROE) has a mean of $5.25 \%$ with a maximum value of $6.376 \%$. As for market profitability (RB) of our sample, it is $11.07 \%$ with a maximum value of $220.53 \%$.

- The variables representing ownership structure: In the overall sample, foreign participation measured by the variable (Foreign) has a mean of $25.45 \%$ with a maximum value of $74.44 \%$. Measuring the dispersion of observations of this variable $(25.28 \%)$ confirms the existence of two categories of financial institutions in our sample. Financial institutions with high foreign ownership and other institutions with minority foreign ownership. Moreover, we note that the variable (Public) has a mean of $26.17 \%$ with a maximum value of $78.55 \%$. In contrast, we find that private property holds the majority of shares of banks and insurance companies in our sample. As a mean this variable has $53.63 \%$ with a maximum value of $84.25 \%$. Similarly, the descriptive statistics on the variable (Bloc) show that the overall sample, the average percentage of shares held by the three major shareholders amounted to $54.98 \%$, which shows that shareholding structure of these companies is concentrated.

Table 2. Descriptive statistics of all variables (13 Tunisian firms, 2000-2011)

\begin{tabular}{cccccc}
\hline Variables & N & Mean & Standard Deviation & Minimum & Maximum \\
\hline ROA & 130 & $1,05 \%$ & $1,76 \%$ & $-11,5 \%$ & $7,35 \%$ \\
ROE & 130 & $5,25 \%$ & $26 \%$ & $-18,75 \%$ & $6,376 \%$ \\
RB & 130 & $11,07 \%$ & $45,71 \%$ & $-81,05 \%$ & $220,53 \%$ \\
Foreign & 130 & $25,45 \%$ & $25.28 \%$ & 0 & $74.44 \%$ \\
Public & 130 & $26,17 \%$ & $26.73 \%$ & 0 & $78.55 \%$ \\
Private & 130 & $53,63 \%$ & $17,42 \%$ & $16,245 \%$ & $84,25 \%$ \\
Bloc & 129 & $54,98 \%$ & $18,08 \%$ & $17,01 \%$ & $87,99 \%$ \\
Branch & 123 & 87,99 & 39.87 & 0 & 149 \\
TCCA & 130 & $7,99 \%$ & $12,05 \%$ & $-48,98 \%$ & $89,25 \%$ \\
\hline
\end{tabular}

Control variables: We introduce two control variables to take into account the growth of financial institutions in our sample. The first variable Branch has a mean of 87.99 with a maximum value of 149 branches. Measuring the dispersion of observations of this variable $(39.87 \%)$ shows the difference in size between the financial institutions in our sample. The second variable (TCCA) corresponds to sales growth of banks and insurance companies. TCCA has a mean of $7.99 \%$ with a maximum value of $89.25 \%$.

\subsection{Interpretations of Results}

In order to assess the different correlations between profitability and its determinants, we will interpret the significance of each variable in the 3 models.

- Foreign Ownership (Foreign): In the first step, we analyzed the impact of foreign ownership on the economic profitability of financial institutions. The estimation results of the model (ROA) indicate that the effect of foreign ownership on return on assets is positive (0.3254) and significant at the 5\% level. In other words, an increase in foreign ownership causes an increase in economic efficiency. This result confirmed the work of Bukhari et al. 
(2005) on 81 developing countries who found that participation of a strategic foreign investor improves profitability. Similarly, we show that the effect of foreign ownership on return on equity (ROE) is positive $(\mathrm{P}=$ 3.5965) and significant at $10 \%$. This result supports the empirical work of Ben Naceur et al. (2007) on the MENA countries including Tunisia context. they demonstrated that return on equity (ROE) is positively related to foreign ownership. Both results confirm our hypothesis and show that foreign partners will pursue the objective of maximizing the shareholders' wealth rather than maximizing employment or production.

- Public property (Public): our results show a positive (0.3265) and significant effect of public ownership on return on assets (ROA). Moreover, this significant effect is also on the implying that an increase in public ownership causes an increase in profitability. These results are surprising since they infirmed our hypothesis. However, they support the study of Bukhari et al. (2005), which shows that when public ownership decreases efficiency (profits) is lower. Furthermore, these results confirmed also the work of Gupta $(2001,2005)$ who showed that partially privatized and state-owned firms seem to perform better than fully privatized companies.

- Private Property (Private): The analysis of the impact of private property (Private) on return on assets (ROA) is positive (0.3528) and significant at the 5\% level, indicating that an increase in private property causes an increase in return on assets. Similarly, the effect of this variable on return on equity (ROE) is positive ( $\mathrm{P}=$ 3.7326) and significant at $10 \%$. These results imply that the presence of institutional investors seems to have a simultaneous positive effect on return on assets and return on equity through their controls in a way they reduce agency costs thereby increasing profitability. On the contrary, the analysis of the impact of private ownership on stock returns is not significant.

Table 3. Summary of results of the three models

\begin{tabular}{|c|c|c|c|}
\hline & Model 1 & Model 2 & Model 3 \\
\hline \multirow[t]{3}{*}{ variables } & ROA (random effet) & ROE (random effet) & RB (fixed effet) \\
\hline & Coefficients & Coefficients & Coefficients \\
\hline & (t-student) & (t-student) & (t-student) \\
\hline \multirow[t]{2}{*}{ Foreign } & $0,3254 * *$ & $3,5965^{* * *}$ & 2,4689 \\
\hline & $(2,01)$ & $(1,45)$ & $(0,46)$ \\
\hline \multirow[t]{2}{*}{ Public } & $0,3265^{* *}$ & $3,7326 * * *$ & 2,0956 \\
\hline & $(2,01)$ & $(1,66)$ & $(0,46)$ \\
\hline \multirow[t]{2}{*}{ Private } & $0,3528 * *$ & $3,7326 * * *$ & 2,6654 \\
\hline & $(2,01)$ & $(1,66)$ & $(0,46)$ \\
\hline \multirow[t]{2}{*}{ FBoard } & $0,0159^{* *}$ & 0,0498 & $0,3409 * * *$ \\
\hline & $(2,14)$ & $(0,70)$ & $(1,95)$ \\
\hline \multirow[t]{2}{*}{ Bloc } & 3,3254 & $-0,0099$ & 0,029 \\
\hline & $(0,03)$ & $(-0,61)$ & $(0,98)$ \\
\hline \multirow[t]{2}{*}{ Branche } & 0,00099 & $-0,0029$ & $0,0059 *$ \\
\hline & $(0,21)$ & $(-0,49)$ & $(3,45)$ \\
\hline \multirow[t]{2}{*}{ TCCA } & $-0,0040$ & 0,1686 & $-0,121$ \\
\hline & $(-0,30)$ & $(1,15)$ & $(-0,62)$ \\
\hline \multirow[t]{2}{*}{ Intercept } & $-36,031 * *$ & $-401,62 * * *$ & $-301,312$ \\
\hline & $(-2,01)$ & $(-1,80)$ & $(-0,67)$ \\
\hline $\mathbf{R}^{2}(\%)$ & $\mathrm{R}^{2}:$ between $=19.21$ & $\mathrm{R}^{2}$ : between $=17,51$ & $\mathrm{R}^{2}:$ within $=27,51$ \\
\hline
\end{tabular}

Note. * significance at $1 \%, * *$ significance at the $5 \%$ level, $* * *$ significance at the $10 \%$ level.

- Foreign Directors (Fboard): The effect of the presence of foreign directors on return on assets (ROA) is positive $(0,0159)$ and significant at the $5 \%$ level, suggesting that the presence of foreign directors in the board causes an increase in return on assets. Furthermore, this result supports the predictions of Lars and Trond (2003) and Choi and Hasan (2005) who argue that the foreign directors can enhance the firm's reputation and value in the financial market. Having a foreign member on the board of directors, it is an indicator of greater company's commitment to corporate monitoring. This can improve in turn the company performance. Moreover, the effect of the variable (Fboard) on stock return $(\mathrm{RB})$ is positive $(\mathrm{P}=0.3409)$ and significant at $10 \%$. In other words, foreign directors contribute to the improvement of stock return as they seek to satisfy shareholders' interests. However, the impact of this variable on return on equity is not significant. 
- Large Shareholders (Bloc): Many studies found a positive relationship between the presence of controlling shareholders and profitability. The estimated coefficients of the variable Large Shareholders (Bloc) admit no significant effects on firms' profitability (ROA, ROE, RB). These results are also obtained by Bukhari et al (2005), suggesting that variations in performance are generally independent from of the identity of the majority owner. Indeed, large shareholders of banks and insurance companies are more likely occupied in maximizing private benefits that are not shared by other stockholders which may explain no relationship between this variable and firms 'profitability.

- The number of branches (branch): We find that the number of bank branches has no significant effect on assets profitability $(\mathrm{P}=0.00099)$ and return on equity $(\mathrm{P}=-0.0029)$. This negative correlation reflects the fact that an expansion of branch networks in the framework of a program of reform and restructuring, especially following the act of partnership, is assumed to incur additional operational costs including internal deployment of branches, revision procedures of the organization. These actions impose costs that reduce return on equity. Similarly, this variable has a positive coefficient $(\mathrm{P}=0.006)$, significant of $1 \%$ on stock return. This relationship is justified by the fact that the establishment of new branches along with by new opportunities for modernization like the introduction of new technologies and new product lines, the development of technical sales and distribution mechanisms are likely to improve market profitability.

- Turnover growth rate (TCCA): Whatever the nature of the return (of assets, equity and stock return), the variable TCCA has no significant effect for the three independent variables. These results indicate that turnover is not a suitable indicator to measure growth.

\section{Concluding Remarks}

This paper has examined the importance of the presence of foreign investors as a key of economic performance. The previous studies found that firms partially privatized seem to be more successful than fully privatized firms. Like most developing countries, Tunisia's economy has been going through a reform process after decades of state control. This transformation aims at promoting foreign investment, restructuring of public enterprises and encouraging a commitment to a crucial program which develops partnership with foreign financial institutions.

In the empirical analysis of this subject, we tried to examine the impact of foreign ownership on the profitability of Tunisian financial institutions. To this end, we tried to determine the relationships between the foreign ownership variables and financial, economic and market profitability. We developed three models that relate the variables of profitability based on ownership structure including foreign ownership, private ownership and public ownership and other variables like the presence of foreign directors in the board of directors and concentrated ownership. The key finding obtained from this empirical study indicates that the presence of foreign partners in the capital of financial institutions seems to have a positive and a significant effect on returns on assets (ROA) and equity (ROE). However, we found that foreign ownership shows no effect on market profitability (RB). Finally, the empirical tests showed that foreign members of the board have a positive and significant impact on economic viability and market profitability.

Certainly, our research could provide acceptable results and give an idea about the characteristics of foreign participation in Tunisia. In a number of ways, the limitations we encounter are mainly related the sample size which is relatively small compared to studies that have examined the relationship between profitability of financial institutions and foreign ownership. As an extension of this study, a research seems particularly interesting that examines the impact of the behavior of foreign investors on degree of success of a partnership with Tunisian financial institutions. Future research should explore the segment differences and the effect of various degrees of foreign ownership, and that this focus can be extended.

\section{References}

Alexandre, H., \& Charreaux, G. O. (2004). Efficiency of French privatizations: A dynamic vision. Journal of Corporate Finance, 10, 467-494. http://dx.doi.org/10.1016/S0929-1199(02)00044-5

Amess, K., Du, J., \& Girma, S. (2009). Full and Partial Privatization in China: The Labor Consequences. Nottingham University Business School Research Paper No. 2009-17. http://dx.doi.org/10.2139/ssrn.1448550

Ben Naceur, S., Ghazouani, S., \& Omran, M. (2007). The performance of newly privatized firms in selected MENA countries: The role of ownership structure, governance and liberalization policies. International Review of Financial Analysis, 16, 332-353. http://dx.doi.org/10.1016/j.irfa.2006.09.006

Berger, A. N., Buch, C. M., DeLong, G., \& De Young, R. (2004). Exporting financial institutions management via foreign direct investment mergers and acquisitions. Journal of International Money and Finance, 23, 
333-366. http://dx.doi.org/10.1016/j.jimonfin.2004.01.002

Boubakri, N. J., Cosset, C., \& Guedhami, O. (2005). Liberalization, corporate governance and the performance of privatized firms in developing countries. Journal of Corporate Finance, 11, 767-790. http://dx.doi.org/10.1016/j.jcorpfin.2004.05.001

Boubakri, N., Cosset, J. C., Fischer, K., \& Guedhami, O. (2005). Privatization and bank performance in developing countries. Journal of Banking \& Finance, 29(8-9). http://dx.doi.org/10.1016/j.jbankfin.2005.03.003

Choi, S., \& Hasan, I. (2005). Ownership, governance, and bank performance: Korean experience. Financial Markets, Institutions \& Instruments, 14(4), 215-242. http://dx.doi.org/10.1111/j.0963-8008.2005.00104.x

Claessens, S., Demirgüç-Kunt, A., \& Huizinga, H. (2001). How Does Foreign Entry Affect the Domestic Banking Market? Journal of Banking \& Finance, 25, 891-911. http://dx.doi.org/10.1016/S0378-4266(00)00102-3

Demirguc-Kunt, A., \& Detragiache, E. (1998). Financial liberalization and financial fragility. IMF WP N83, pp. 1-34. http://dx.doi.org/10.1596/1813-9450-1917

Dinger, V. (2009). Do foreign-owned banks affect banking system liquidity risk? Journal of Comparative Economics, 37, 647-657. http://dx.doi.org/10.1016/j.jce.2009.04.003

Gupta, N. (2001). Partial Privatization and Firm Performance: Evidence from India. William Davidson Working Paper Number 426 December 2001. http://dx.doi.org/10.2139/ssrn.294560

Gupta, N. (2005). Partial Privatization and Firm Performance. The Journal of Finance, x(2), April 2005. http://dx.doi.org/10.1111/j.1540-6261.2005.00753.x

Haspeslagh, P. C., \& Jemison, D. B. (1991). Managing Acquisitions. Creating Value through Corporate Renewal. Long Range Planning, 24(5), 138-139. http://dx.doi.org/doi:10.1016/0024-6301(91)90291-U

La Porta, R., Lopez-de-Silanes, F., \& Shleifer, A. (2002). Government ownership of banks. Journal of Finance, 57. http://dx.doi.org/10.1111/1540-6261.00422

La Porta, R., Lopez-de-Silanes, F., Shleifer, A., \& Vishny, R. (1999). The quality of government. Journal of Law, Economics, and Organization, forthcoming. http://dx.doi.org/10.1093/jleo/15.1.222

Lars, O., \& Trond, R. (2003). The impact of foreign board membership on firm value. Journal of Banking and Finance, 27(12), 2369-2392. http://dx.doi.org/10.1016/S03784266(02)00395-3

Lensink, R., \& Naaborg, I. (2007). Does foreign ownership foster bank performance? Applied Financial Economics, 17(11), 881-885. http://dx.doi.org/10.1080/09603100600827653.

Lensink, R., \& Naaborg, I. (2008). Banking in transition economies: Does foreign ownership enhance profitability? The European Journal of Finance, 14(7), 545-562. http://dx.doi.org/10.1080/13518470701322268

Leroux, V., \& Sauvée, L. (2004). XIIème conférence de l'Association International de Management Stratégique, Juin 2004.

Levine, R. (2004). Denying foreign bank entry:implications for bank interest margins. Central Bank of ChileWorking Paper 222.

Lin, X., \& Yi, Z. (2009). Bank ownership reform and bank performance in China. Journal of Banking \& Finance, 33, 20-29. http://dx.doi.org/10.1016/j.jbankfin.2006.11.022

Mamoghli, C., \& Dhouibi, R. (2009). Quel est l'impact de la propriété publique sur la rentabilité des banques? Cas des banques tunisiennes. Rapport de recherché, Institut Supérieur de Gestion de Tunis.

Maw, J. (2002). Partial privatization in transition economies. Department of Economics, University of Wales Swansea, Singleton Park, Swansea SA2 0LT, UK. Economic Systems, 26, 271-282. http://dx.doi.org/10.1016/S0939-3625(02)00047-X

Megginson, W. (2005). The economics of bank privatization. Journal of Banking and Finance, 29, 1931-1980. http://dx.doi.org/10.1016/j.jbankfin.2005.03.005

Megginson, W., \& Netter, J. (2001). From State to Market: A Survey of Empirical Studies on Privatization. Journal of Economic Literature, 321-389. http://dx.doi.org/10.2139/ssrn.262311

Roosenboom, P., Van Der Goot, T., \& Mertens, G. (2003). Earnings management and initial public offerings: 
Evidence from the Netherlands. The International Journal of Accounting, 38, 243-266. http://dx.doi.org/10.1016/S0020-7063(03)00048-7

Wu, X., \& Strange, R. (2000). The location of foreign insurance companies in China. International Business Review, 9, 383-398. http://dx.doi.org/10.1016/S0969-5931(00)00007-X

\section{Notes}

Note 1. Financial liberalization is defined as the passage from one state of repression to another state for liberalizing the rapid and efficient financing of production and the investment of the economy through free movement of capital as well.

Note 2. Arab Tunisian Bank (ATB), Attijari Bank, BH Bank, BIAT Bank, BNA Bank, UIB Bank, BT Bank, BTE Bank, STB Bank, UBCI Bank, Amen Bank. STAR insurance company and ASTREE Tunisia Insurance company.

Note 3. We suppose no intermediate dividends.

Note 4. Cheng HSIAO, 1986, Analysis of Panel DATAT, Combrige University Press.

\section{Copyrights}

Copyright for this article is retained by the author(s), with first publication rights granted to the journal.

This is an open-access article distributed under the terms and conditions of the Creative Commons Attribution license (http://creativecommons.org/licenses/by/3.0/). 